\title{
Синтез культур и квазиисторическая традиция в учении Георгия Гурджиева
}

\author{
А.Н. Мошкин \\ Белгородский государственный национально-исследовательский университет, \\ Россия, 308015, г. Белгород, ул. Победы, 85 \\ E-mail: moshkin@bsu.edu.ru
}

\begin{abstract}
Аннотация. В данной работе рассматриваются философские взгляды отечественного философамистика первой половины XX в. армяно-греческого происхождения Георгия Гурджиева. В статье доказывается, что философское учение Гурджиева было ответвлением интегрального традиционализма, имея отечественную специфику. В частности, Гурджиев подвергает резкой критике современное европейское общество, его науку и культуру, упрекая его в деградации и стремясь обратиться к древнему правильному учению. При этом Гурджиев опирался на идеи русского космизма, православного христианства и религиозные практики среднеазиатских суфиев, а также синтез других религий. Он был не только теоретиком интегрального традиционализма, но и практиком, реализуя свое учение в основанном им Институте гармонического развития. Суть учения Гурджиева состояла в том, что человек является неотъемлемой частью природы и космоса, но природа человечества искажена, оно деградировало и забыло свои функции в современном мире. Необходимо применять практики Четвертого пути, предполагавшие самосовершенствование и внутреннюю работу над собой для духовного роста и пробуждения совести. Гурджиев практиковал гипноз. Важную роль для Гурджиева играли кавказские и среднеазиатские народные традиции.
\end{abstract}

Ключевые слова: Гурджиев, Институт гармонического развития, Четвёртый путь, интегральный традиционализм, русский интегральный традиционализм, мистицизм, русский космизм, русская философия, армянская философия.

Для цитирования: Мошкин А.Н. 2021. Синтез культур и квазиисторическая традиция в учении Георгия Гурджиева. Via in tempore. История. Политология, 48 (1): 211-229. DOI: $10.52575 / 2687-0967-2021-48-1-211-229$.

\section{The synthesis of cultures and quasi-historical tradition in the teachings of George Gurdjieff}

\author{
Aleksandr N. Moshkin \\ Belgorod National Research University, \\ 85 Pobedy St., Belgorod, 308015, Russia \\ E-mail: moshkin@bsu.edu.ru
}

\begin{abstract}
Annotation. This work examines the philosophical views of the Russian mystic philosopher of Armenian-Greek origin George Gurdjieff who lived in the first half of the 20th century. The author proves that the philosophical doctrine of Gurdjieff was an offshoot of integral traditionalism, having a domestic specificity. In particular, Gurdjieff sharply criticizes modern European society, its science and culture, reproaching it for degradation and seeking to turn to the ancient correct teaching. At the same time, Gurdjieff relied on the ideas of Russian cosmism, Orthodox Christianity and the religious practices of the Central Asian Sufism, as well as a synthesis of other religions. He was not only a theoretician of integral traditionalism, but also a practitician, realizing his teachings in the Institute of Harmonious Development founded by him. The essence of Gurdjieff's teaching was that man is an integral part of nature and space, but the nature of mankind is distorted, it has degraded and has forgotten its functions in
\end{abstract}


the modern world. It is necessary to apply the practices of the Fourth Way, which involved selfimprovement and inner work on oneself for spiritual growth and the awakening of conscience. Gurdjieff practiced hypnosis. The tradition on which Gurdjieff relied was pseudo-historical, apparently invented by him the Sarmung Brotherhood from Central Asia, associated with the ancient Babylonian civilization. Caucasian and Central Asian folk traditions played an important role for Gurdjieff.

Key words: Gurdjieff, Institute of Harmonious Development, the Fourth Way, integral traditionalism, Russian integral traditionalism, mysticism, Russian cosmism, Russian philosophy, Armenian philosophy.

For citation: Moshkin A.N. 2021. The synthesis of cultures and quasi-historical tradition in the teachings of George Gurdjieff. Via in tempore. History and political science, 48 (1): 211-229 (in Russian). DOI: $10.52575 / 2687-0967-2021-48-1-211-229$.

Идея данной работы принадлежит д. и. н., проф. А.Ж. Арутюняну (Ереван, Армения), земляку Гурджиева. Реализация темы стала возможной благодаря дружеской помощи д. и. н., проф. Н.Н. Болгова (НИУ «БелГУ»), который обратил наше внимание на широкий контекст архаизма-традиционализма 1-й пол. ХХ в. в плане рецепции древности в контексте кризиса западной цивилизации (Р. Генон, Э. Юнгер, Ю. Эвола и др.).

Тема данной работы касается исследования жизни и творческой деятельности отечественного мыслителя, философа-мистика, путешественника, музыканта и врача Георгия Гурджиева [Ровнер, 2002] в контексте развития российского направления интегрального традиционализма. Интегральный традиционализм как философское течение сложился в последней четверти XIX - 1-й пол. XX в. как ответ на кризис европейской культуры, связанный с наступлением эпохи модерна. Это время промышленной революции, механизации и индустриализации, связанной с развитием техники и машинного производства, сопровождавшейся урбанизацией и секуляризацией сознания, научно-технической революцией [Пильчинова, 2014, с. 22-25]. Урбанизация способствовала формированию массовой культуры, которая вытесняла и примитивизировала культуру элит. Фундаментальные открытия в естественнонаучном знании (электромагнитное излучение, строение атома, периодическая система элементов, радиоактивность, теория биологической эволюции и генетика и др.) вывели его на новый уровень и привели к кризису религий, развитию атеизма. Это привело к кризису духовности в Европе [Орлов, 2006, с. 130-148].

В условиях кризиса господствующей в Европе христианской религии духовный поиск среди интеллигенции был направлен на альтернативные религиозные традиции Европы: эзотерику, оккультизм, теософию, масонство и религиозные системы Востока: ислам, буддизм и индуизм, иудаизм. На их основе и сложился интегральный традиционализм [Полонская, 2005, с. 30-36]. Интегральный традиционализм стал реакцией на кризис религии и традиционной европейской культуры, представляя собой консервативное религиознофилософское учение, направленное на сохранение и возрождение древних ценностей, институтов и религиозных практик, переданных через многовековой опыт и практическую мудрость [Холодов, Молотов, 2010, с. 4-9]. В интегральном традиционализме критикуется утративший духовность современный мир, происходит попытка отказа от него и его ценностей, а также попытка возвращения к первоначальным истокам человеческой культуры и восстановлению духовности, выражавшихся в идеализированной и единой для всех примордиальной (первоначальной) Традиции. Интегральный традиционализм отрицает идею прогресса, считая, что происходят инволюция и деградация человеческого общества. Полная Традиция в современном мире утрачена, но ее части сохранились и были переданы религиозные системы и учения, так как религия является наиболее консервативной сферой культуры [Седжвик, 2014, с. 35-36]. Для традиционалистов Западной Европы характерен отказ от канонического христианства - как католичества, так и протестантизма, - как слишком рационализированных и утративших остатки Традиции, и духовный поиск в более кон- 
сервативных религиозных учениях Востока с обращением к национальной дохристианской мифологии и античной культуре [Филиппович, 2014, с. 51-62].

Особые черты традиционалистические идеи имели в России, так как она не является типично западной цивилизацией, а лежит на стыке Запада и Востока, включая в себя обе из цивилизационных составляющих [Кравченко, 2020, с. 174-187]. Культура и религиозные традиции неправославных народов Средней Азии и Кавказа, находящихся в Российской империи, оказывали непосредственное влияние на развитие русской культуры, вступая в прямое взаимодействие со славянской культурой. Кроме того, в отличие от Западной Европы, в России были сильны позиции православного христианства, которое отнюдь не исчерпало себя как источник духовной жизни. Эти черты оказали непосредственное влияние и на формирование философского учения Георгия Гурджиева, который является ярким представителем отечественной ветви интегрального традиционализма.

Помимо общих культурных особенностей русской цивилизации складывание традиционалистического мировоззрения Гурджиева напрямую связано с перипетиями его жизни и деятельности. Собственно говоря, Георгий Гурджиев не был непосредственным продуктом русской философско-мистической школы. Он родился и вырос на Кавказе в полиэтничной культурной среде [Алексахин, 2003], что предопределило огромное влияние на него культуры Кавказа и Средней Азии. Поэтому для понимания его учения необходимо подробно рассмотреть биографию философа. Ее можно узнать как из автобиографических зарисовок философа в его работах, это касается раннего и зрелого периода его жизни, так и из работ, содержащих воспоминания его учеников, - это относится ко второй половине жизни Гурджиева.

Георгий Иванович Гурджиев родился в 1873 (по другим версиям, в 1866, 1872, 1874 или 1877) году в городе Александрополь (ныне Гюмри, Армения) [Алексахин, 2003; Бровко, 2019, с. 6; Ровнер, 2002] в семье грека Иоаннеса Георгиадеса, происходящего из Каппадокии [Кравченко, 1997, с. 213]. Его семья переехала из Турции сначала в Грузию, а потом он сам уехал в Армению. Отец Гурджиева был богат, владел несколько стадами, но затем обнищал из-за падежа скота. Это его не расстроило, так как он ценил духовные ценности выше материальных, чему научил и детей. А сам он являлся ашугом - сказителем устных народных песен [Гурджиев, 2018b, с. 29-30, 38, 45-46]. Матерью философа была армянка из рода Тавризовых-Багратуни. Фамилия «Гурджиев» переводится с турецкого как «грузин», «выходец с Кавказа». Такую фамилию носили многие малоазиатские греки, эмигрировавшие на другую сторону Кавказа, в Армению [Алексахин, 2003].

Отец был знатоком многих народных песен и часто исполнял их, чем заложил в старшем сыне огромную любовь к народному фольклору. Георгий Гурджиев часто в своих произведениях впоследствии использовал выразительные речевые обороты, пословицы и поговорки для разъяснения своих идей в просторечье. Кроме того, одним из самых любимых и авторитетных источников для Гурджиева являлся знаменитый полуфольклорный персонаж, распространенный на территории Кавказа, Центральной и Средней Азии, а также Ближнего Востока в турецкой, арабской, персидской и даже китайской традиции философ Ходжа Насреддин, дату жизни которого относят к XIII в. [Гордлевский, 1957]. Его Гурджиев почтительно называет Мулла Наср-Эддин [Гурджиев, 2004, с. 10] и вкладывает в его уста большую часть всех поговорок и ярких ироничных выражений, которые использует в своем произведении, намеренно относя время жизни философа к XIX в., чтобы через него высмеивать злободневные проблемы современности.

Еще в детстве Гурджиев почувствовал собственную уникальность и исключительность [Гурджиев, 2004, с. 20-26]. Ключевым событием, стимулировавшем его духовные поиски, в дальнейшем стал эпос о Гильгамеше. Из всех народных песен и сказаний, которые исполнял его отец, наибольшее впечатление на Гурджиева произвел шумерский сказ о Гильгамеше. Впоследствии Гурджиев узнал, что устное предание донесло чуть не слово в слово вавилонский эпос, созданный более 4000 лет назад, найденный археологическими 
раскопками на глиняных табличках [Гурджиев, 2018b, с. 32-34]. Это подтолкнуло молодого человека к поиску наследия древних центров вавилонской культуры. В частности, речь идет о древнейшем религиозном обществе «Сармунгское братство», которое имело древневавилонские корни [Гурджиев, 2018b, с. 91-92].

Юношей Гурджиев получил очень хорошее образование. Его первым учителем был настоятель собора в Карсе, священник Борш. Помимо своих священнических обязанностей Борш увлекался астрономией, химией и музыкой, к чему пристрастил своего воспитанника. По совету и под руководством Борша Гурджиев получил глубокое домашнее образование, изучив русский язык, Священное Писание, географию, историю, анатомию, физиологию, математику. Также Гурджиев любил читать книги, особенно древние, поглощая их со страстью [Гурджиев, 2018b, с. 48-51]. К чтению пристрастил его второй учитель, священник Евлиссий Богаевский, заменивший Крестовского, а впоследствии ставший аббатом Ессейского братства в монастыре около Мёртвого моря [Гурджиев, $2018 b$, с. 56, 59, 72]. Впоследствии Гурджиев указывал, что Ессейское братство в наиболее правильной форме донесло учение Христа до современности [Гурджиев, 2004, с. 398].

Родители Гурджиева хотели, чтоб тот стал священником, но наставник советовал освоить профессию врача [Гурджиев, 2018b, с. 50, 51]. В итоге Гурджиев выбрал средний путь, освоив профессию врача-гипнотезёра, то есть психолога. А сам он увлекался техническими науками, переняв от отца удивительное мастерство в починке различных инструментов и приборов, производстве ремесленных изделий, а также умел шить, красить, работать по дереву, металлу, керамике и другим материалам, считаясь мастером на все руки в родном городе [Гурджиев, 2018b, с. 280-281].

Кроме того, живя в условиях полиэтничности в окружении различных народов, Гурджиев был необычайным полиглотом и владел 18 языками, в основном, восточными. С детства Гурджиев владел армянским и русским. Также родители для него наняли учителя новогреческого языка, знавшего и турецкий - оба он хорошо знал [Гурджиев, 2004, с. 13, 23; Гурджиев, 2018b, с. 328]; кроме того, прекрасно владел персидским [Гурджиев, $2018 b$, c. 196, 263], изучил грузинский, узбекский и его особый диалект сартский, киргизский и арабский [Гурджиев, 2018b, с. 110, 121, 232-233, 261-262]. Также он хорошо знал итальянский [Гурджиев, 2018b, с. 121]. Другие западноевропейские языки, а именно: французский, английский, немецкий, Гурджиев изучил в позднем возрасте, когда эмигрировал в Европу [Гурджиев, 2004, с. 17-18, 374-375; Гурджиев, 2018b, с. 329-331]. Немецкий он знал плохо. Не исключено, что он знал и латинский, цитаты из которого также использовал в своих работах [Гурджиев, 2004, с. 241, 283-285]. Языкам и их грамматике Гурджиев придавал важное значение при написании своих произведений [Гурджиев, 2004, c. 10-12].

В юности Гурджиев стал свидетелем различных чудес и мистических событий, которые его очень заинтересовали и обратили к исследованию эзотерических наук и сверхъестественных явлений; он стал искать ответы на свои вопросы в древней литературе. Вместе с друзьями Гурджиев образовал «Общество искателей истины» [Гурджиев, 2018b, c. 60-69, 227]. Также он начал участвовать в различных географических и археологических экспедициях. Среди развалин города Ани удалось обнаружить пергамен с информацией о Сармунгском братстве [Гурджиев, 2018b, с. 89-92]. Вскоре после находки Гурджиев с другом Погосяном предпринял первое путешествие по Кавказским землям в поисках информации об этом братстве. Им удалось обнаружить древнейшую карту, которая привела их в Египет, в Александрию, где ему довелось познакомиться с еще одним эзотериком - князем Любовецким, а также археологом профессором Скридловым [Гурджиев, 2018b, с. 100-102, 121-123]. Впоследствии Гурждиев принимал участие в археологических экспедициях Скридлова в Среднюю Азию и Закавказье, ездил с князем на Тибет, в Индию и Цейлон, освоил хатха-йогу [Гурджиев, 2018b, с. 123, 196]. Также он увлекался японской борьбой джиу-джитсу [Гурджиев, 2018b, с. 146]. 
В своих духовных поисках Гурджиев посещал Константинополь, Эчмиадзин, Тифлис, а затем отправился в Среднюю Азию - в Бухару и Самарканд [Гурджиев, 2018b, c. $78,110,138,188]$. Именно там он наткнулся на информацию о Сармунгском братстве и познакомился с его членами, предприняв путешествие в монастырь, расположенный в горном Туркестане, которому было не менее 4500 лет. Именно в этом монастыре Гурджиев познакомился со священными суфийскими танцами, ставшими важным аспектом его учения в дальнейшем [Гурджиев, 2018b, с. 152-160, 168-169].

В 1898-1900 гг. вместе с профессором Скридловым, а также своим друзьями из «Общества искателей истины» Гурджиев участвовал в археологических экспедициях в пустыню Гоби, Азербайджан и Персию, Афганистан, Памир, Гималаи, Индию, Тибет и Сибирь, а также Абиссинию, Вавилон и Сирию, а затем снова в Туркестан, в частности Бухару и город Мерве, где год велись раскопки [Гурджиев, 2018b, с. 172-186, 194, 199-205, 228, 241-242, 246, 282, 248-252, 282]. Тем не менее в истории археологических экспедиций в городе Мерве не упоминается археолог Скридлов, хотя там упоминаются даже любители [Лунин, 1958, с. 32-47]. О его археологической деятельности информацию найти не удалось. А разброс «экспедиций» предполагает, что он не был официальным археологом и не состоял в официальных археологических организациях. Как и Гурджиев, Скридлов был «духовным искателем», о чем свидетельствует и специфика их «археологической» подготовки - они заучивали персидские религиозные тексты, выдавали себя за дервишей, купцов и т. п. [Гурджиев, 2018b, с. 183, 263]. Результатом «экспедиций» стало знакомство с различными духовными лидерами, прославленными дервишами и факирамиподвижниками, у которых они черпали информацию о духовных практиках, дыхании, питании [Гурджиев, 2018b, с. 199-205, 228, 241-242, 246, 282].

В ходе одного из путешествий Гурджиев и Скридлов наткнулись на некий монастырь экуменического типа, возглавляемый грекоязычным итальянцем отцом Джованни. Там обитали «бывшие христиане, иудеи, мусульмане, буддисты, ламаисты и даже один шаман» [Гурджиев, 2018b, с. 267]. Этот монастырь был одним из системы 4 монастырей, остальные из которых были расположены на Тибете, в Индии и на Памире. Хотя прямо об этом не сказано, видимо, этот монастырь также относился к мифическому Сармунгскому братству, а Гурджиев до этого посещал другой монастырь братства на Памире. В монастыре в беседах с отцом Джованни Гурджиев и его спутники нашли ответы на все свои вопросы [Гурджиев, 2018b, с. 265-274]. Этим оканчивается духовный поиск Гурджиева.

В целом свидетельств об этом периоде деятельности Гурджиева нет, кроме его собственных автобиографических зарисовок. Весьма вероятно, что он выдумал или исказил многие вещи своей биографии, в частности, это касается поиска Сармунгского братства.

Научившись сам, с 1912 г. Гурджиев начинает учить других. Он прибыл в Москву, а затем в Санкт-Петербург, где стал выступать с лекциями о своем учении. С 1915 г. он знакомится с еще одним философом, увлекавшимся теософией - Петром Успенским. Успенский на этот период стал главным учеником Гурджиева [Ровнер, 2002]. Именно там Гурджиев пытался основать «Институт гармонического развития», в котором развивал свое учение. Но планы прервала сначала Первая мировая война, а затем революция. Гурджиев вынужден был перебраться в Ессентуки вместе со своими учениками [Гурджиев, 2018b, с. 308-309]. Дабы его учеников не мобилизовали на фронт белые или красные (сам он нейтрально относился ко всем враждующим сторонам), Гурджиев организовал «археологическую экспедицию», в ходе которой он с учениками перебрался из Ессентуков в Тифлис. В Тифлисе он организовал филиал своего Института [Гурджиев, 2018b, с. 310-320].

После прихода к власти большевиков Гурджиев и его ученики решили эмигрировать, понимая, что новая власть не позволит им держать собственный институт духовнорелигиозного характера. Они эмигрировали в Константинополь [Гурджиев, 2018b, с. 322]. Там члены Института читали лекции, а Гурджиев сочинял музыку в соответствии со своим учением, привлекая много последователей. Его главным сподвижником в этом деле 
был его ученик, русский композитор Фома Гартман, который познакомился и поступил под начало Гурджиева в 1917 г., последовав за учителем вместе с женой и семьей в Ессентуки, Тифлис и Константинополь, а впоследствии в Германию и Францию, оставаясь с Гурджиевым вплоть до 1929 г., пока последний не отослал своего ученика. Гартман перекладывал напеваемые Гурджиевым мелодии на музыку, так как учитель не знал нотной грамоты, создавая музыкальное сопровождение для танцев членов Института гармонического развития [Свиридовская, 2014, с. 68-85]. В 1921 г. Гурджиев, опасаясь роста турецкого национализма, переехал со своими учениками в Западную Европу, а именно в Германию, в Берлин, а также посетил Лондон в поисках лучшего места для Института. В итоге его выбор остановился на Франции и Париже, где для функционирования Института была арендована вилла Шато дю Приер [Гурджиев, 2018b, с. 325-328] в 1922 году. В 1924 г. Гурджиев отправился в Америку, чтоб там открыть филиал школы. Он и его ученики выступали с лекциями [Алексахин, 2003].

По возвращении во Францию Гурджиев попал в автомобильную аварию, врезавшись в дерево, после которой долго восстанавливался, будучи не в состоянии полноценно работать около 9 месяцев [Гурджиев, 2014, с. 58]. В это время стал прогрессировать рак у его жены, которую он любил и лечил гипнозом. В результате аварии он не смог продолжать курс лечения, и рак перешел в смертельную стадию. Эту автобиографическую историю Гурджиев также вставил в «Рассказы Вельзевула» [Гурджиев, 2004, с. 510-512]. У его матери, эмигрировавшей к сыну во Францию, была тяжелая болезнь печени. От этих болезней обе женщины скончались в 1925-1926 гг. [Гурджиев, 2014, с. 22-26]. О жене мало что известно, кроме того, что Гурджиев горячо ее любил, а познакомился с ней в СанктПетербурге в 1907 г. [Гурджиев, 2014, с. 26]. Ее имя было Юлия Островская [Ровнер, 2002]. После этого Гурджиев стал писать свои работы, закрыв Институт во Франции, но оставив его филиал в Америке в Нью-Йорке, где деятельность по поддержанию Института осуществлял его ученик Оридж [Гурджиев, 2014 с. 57-58]. С 1927 по 1934 г. Гурджиев пребывал в Америке [Уэлш, 2002, с. 145-166]. Период писательской деятельности Гурджиева продолжался в течение 7 лет с 1928 года по 1935 г. [Гурджиев, 2014, с. 31]. После этого Гурджиев прекратил писать.

Одной из насущных проблем для Гурджиева было поддержание своего материального благополучия и поиск денег не только на жизнь, но и на свои исследования. Гурджиев описывает много ситуаций, когда в незнакомом городе он имел около нескольких копеек и вынужден был воровать плоды с огородов [Гурджиев, 2018b, с. 139]. Зарабатывал себе на жизнь Гурджиев не интеллектуальной деятельностью, а ремеслом и торговлей, иногда его предприятия были на грани мошенничества. Он торговал книгами, гипсовыми фигурками, бумажными цветами, птицами, рыбой, проводил экскурсии, чистил обувь, был шарманщиком, работал ныряльщиком, организовывал ремесленные мастерские по починке приборов, делал корсеты, перегонял скот, открывал рестораны и театры, участвовал в нефтедобыче, выдавал себя за дервиша и факира, в более поздний период в России и Европе работал врачом-гипнотизёром. В период революции скупал, реставрировал и продавал ковры и антиквариат. В ходе своей деятельности он смог заработать к 1913 году до 1 млн рублей, пользуясь репутацией ловкого и удачного бизнесмена [Гурджиев, 2018b, c. $110,112-113,122,140-151,189-191,207-215,259,279,285-300,306]$, что стало базисом для открытия института. В Европе Гурджиев также занимался коммерческой деятельностью, вкладывал деньги в нефтяные компании, открыл два ресторана на Монмартре, а также работал врачом-психологом, основывая свои методы лечения на гипнотических сеансах. Ученики отмечали, что Гурджиев устраивал различные обеды для своих последователей и был превосходным поваром [Клостре, 2002, с. 167-173]. В одной из лекций он сообщает, что учился изготовлять духи в молодости [Гурджиев, 2009b]. В период своей эмигрантской деятельности Гурджиев не чурался просить деньги у собственных учеников. В 1924 г. Гурджиев организовал турне по Америке, чтобы собрать денег на оплату долгов 
во Франции, освоив английский язык. В бытность своего пребывания в Америке после 1927 г. он занимался скупкой и перепродажей антиквариата для содержания Института, но Великая депрессия 1929-1933 гг. сильно ударила по его бизнесу и разорила его [Гурджиев, 2018b, с. 342-350].

После второго приезда в Америку Гурджиев очень материалистически подходил к своей школе и, по выражению ученого А. Ровнера, стриг деньги с учеников, как с овец [Ровнер, 2002]. Кроме того, он боролся за влияние на последователей своего ученика Ориджа, конкурируя с собственным учеником, которого называл незрелым и исказившим его идеи [Гурджиев, 2014, с. 71-74]. Также достаточно цинично он поступал с письмами своих последователей, говоря секретарю вскрывать лишь те, которые «с вложениями», остальные уничтожать. У него также была система распределения приходящих средств в зависимости от суммы [Гурджиев, 2014, с. 40-41]. Поведение Гурджиева было очень эксцентрично, он довольно высокомерно относился к Ориджу, требуя у него денег. Вскоре это спровоцировало разрыв между ними. Американская группа Гурджиева вскоре распалась, и он вернулся во Францию [Ровнер, 2002].

С 1933 по 1936 г. Гурджиев находился в отчаянном материальном положении. Он пытался привлечь последователей, даже установить контакты с советским руководством, совершил краткосрочную неудачную поездку в Центральную Азию [Ровнер, 2002]. В этот период он распустил старых учеников, продал виллу Шато дю Приер и переселился в русский квартал Парижа. Изданная им на 9 языках книга «Вестник грядущего добра» провалилась, о чем он сам писал [Гурджиев, 2014, с. 33]. В это время вокруг него собралась новая группа из женщин литературно-лесбийских кругов [Baker, 2000]. Беседы проходили в форме торжественных застолий, где Гурджиев вел себя по-прежнему эксцентрично, но стал более доступен [Уэлш, 2002]. Пользуясь своей харизмой, он встречался со своими ученицами, от которых, как подозревается, у него были дети [Taylor, 1998, p. 3]. Детей он любил, всегда угощал их конфетами и орехами [Ровнер, 2002].

В годы Второй мировой войны он также устраивал застолья, имел в запасе склад продуктов, поддерживал учеников и соседей, укрывал учеников-евреев. В 1948 г. после смерти отколовшегося от него ученика Успенского Гурджиев объединил всех английских учеников последнего, критикуя Успенского, а также собрал американских последователей, посетив США. Его наиболее близким учеником был Дж. Беннет, с которого он также брал деньги, конкурировал за учеников, развивая тему об учениках-«иудах», которые исказили его учение (Успенский, Оридж) [Ровнер, 2002]. В 1948 г. с ним приключилась еще одна автомобильная авария, вконец подорвавшая его здоровье [Беннет, 2006, с. 224]. Он с трудом поддерживал свое существование, еле передвигаясь, а в 1949 году скончался. Перед смертью он успел подержать в руках издание своей главной книги «Рассказы Вельзевула», написанной еще в 1935 г. [Ровнер, 2002]. После его смерти все ученики горевали, так как Гурджиев был харизматичной личностью [Алексахин, 2003]. Они продолжили поддерживать и развивать идеи своего наставника, собирая его наследие [Греков, 2013b, c. 14-19].

В основе учения Гурджиева лежали идеи саморазвития и духовного восхождения, связанные с самонаблюдением своего внутреннего духовного состояния и преодолением пороков, пробуждением мысли [Греков, 2013c]. Гурджиев считал человека частью природы, который с ней неразрывно связан. Он разделял идеи русского космизма, основанного на том, что связь человека и Бога проходит через Космос, не просто Вселенную, а некое живое и разумное мироздание, пронизанное духом Божественного присутствия, а устройство макрокосмоса воспроизводит микрокосмос внутри человека [Куракина, 2014]. По мнению Гурджиева, человек - это результат взаимодействия планетарных эманаций и земной атмосферы, а после смерти его физическое тело распадается, а астральное существует в космосе. В нем может развиться третье тело - ментальное [Гурджиев, 2018а, с. 23]. 
Также учение Гурджиева включало в себя традиционалистический пласт, связанный с идеями о деградации человечества в течение его существования на Земле. Природа человека была искажена изначально, а в ходе человеческого развития произошла утрата первоначальных знаний и мудрости, позволявших человеку преодолеть свою ограниченность и достигнуть самосовершенствования [Кучеренко, 2005]. В основе гурджиевской примордиальной Традиции лежит учение таинственного Сармунгского братства, которое имело, по его словам, 5 000-летнюю историю и донесло древние знания и традиции до настоящего времени. Сообщения о Сармунгском братстве кажутся выдумкой Гурджиева, который предстает как мистификатор, использующий эту информацию, чтобы придать авторитет древности своего учения. Аналогичными мистификациями считают слухи о встречах Гурджиева в Тифлисе в семинарии со Сталиным, а в Берлине - с Гитлером [Алексахин, 2003; Бровко, 2019, с. 10-12; Ровнер, 2002]. Политиков философ презирал.

Тем не менее, несмотря на традиционалистические идеи, с другими традиционалистами Гурджиев понимания не нашел, вероятно, из-за претензий на исключительность. Он высмеивал основоположника традиционализма Рене Генона на своих собраниях, а сам французский философ призывал своих учеников бежать от Гурджиева [Ровнер, 2002].

Так или иначе, ссылаясь на авторитет братства, Гурджиев построил собственное учение. Для того, чтобы вернуться к Космосу и слиться с ним в гармонии, человек должен был преодолеть собственную сущность, так как изначально является механистичной машиной [Гурджиев, 2009c, с. 2, 10, 52]. Цель человека - саморазвитие. Гурджиев разработал концепцию четвертого пути для достижения этой цели. Она основана на том, что есть 4 пути самосовершенствования, первые 3 - традиционные в разных религиях: 1) путь факира - преодоление возможностей собственного тела без внимания к духовной составляющей (ислам); 2) путь монаха - борьба со своими эмоциями и страстями без внимания к телесной составляющей (христианство); 3) путь йога - совершенствование разума с контролем тела и эмоций (буддизм). Но все эти пути предполагают уход человека от мира, разрыв связей с ним и природой. Есть высший 4-й путь, который не требует ухода от мира и создания некой искусственной среды, а предполагает самосовершенствование в естественных для человека условиях. Его ключевая составляющая - внутренняя работа над собой путем самонаблюдения, самоанализа и самоконтроля [Греков, 2013a, с. 141-151].

Достижение этого, согласно методам Гурджиева, предполагало преодоление собственных слабостей, очищение через страдание и работу, выполнение неприятных вещей, а также пробуждения мысли и совести через проникновение в подсознание, в том числе путём гипноза [Лемешев, 2019]. Изначально люди рассматривались как механистические машины, чья духовная составляющая дремлет [Кучеренко, 2005]. Методика самосовершенствования была связана с практикой священных суфийских танцев, так как музыка, по мнению Гурджиева, была отражением мировой гармонии, а танцы под музыку приводили человеческое тело в естественное состояние [Кравченко, 1997, с 217]. Для улучшения контроля над собой часто использовалось упражнение «стоп», предполагавшее замирание ученика в той позе, в которой его застал приказ учителя «стоп» и сохранение этого положения сколь угодно долго (пока учитель не отпустит), причем сохраняется не только поза тела, но и неподвижность глаз, мышц и даже мыслей, которые были в голове в момент остановки. Система Гурджиева была очень жесткой, с учениками он не церемонился. Помимо танцев он изнурял их тяжелой работой, в том числе для заработка пропитания, часто оскорблял и унижал [Вандерхилл, 1996, с. 164-180]. Но никто не роптал на это из-за высочайшего авторитета учителя.

Гурджиев в своем учении синтезировал как христианство, так ислам и суфизм, буддизм и иудаизм. Но сам он называл свое учение эзотерическим христианством [Успенский, 2014, с. 121], используя христианский же понятийный аппарат и считая, что все религии, так или иначе, похожи на христианство [Нежинский, 2009]. Впрочем, исследователи считают, что Гурджиев совершенно не был христианином, а был оккультистом [Пита- 
нов, 2016; Лемешев, 2019], что подтверждается и его учением. Например, Иисуса Христа он считает магом или неким космическим ангелом, а не Богом [Гурджиев, 2004, с. 63; Гурджиев, 2009с, с. 140; Гурджиев, 2018а, с. 21].

Систематическое изложение учения Гурджиева дано в его работах, которые делились автором на 3 серии в соответствии с тем, как надо постигать его учение. Всего он выпустил 10 книг. В первой серии - 3 книги под общим названием «Рассказы Вельзевула», во второй серии - 3 книги под общим названием «Встречи с замечательными людьми», в третьей серии - 4 книги, объединенные названием «Жизнь реальна только тогда, когда "Я есть“» [Гурджиев, 2004, с. 6; Гурджиев, 2014, с. 1; Гурджиев, 2008c].

Главной работой Гурджиева является его работа в виде фантастической сказки «Все и вся. Объективно-беспристрастная критика жизни человека, или Рассказы Вельзевула своему внуку», которая объединяет в 48 главах 3 книги первой серии [См.: Гурджиев, 2004]. Эта книга предназначена детям, так как воспитанию детей Гурджиев уделял большое внимание. Ведь правильное воспитание (каковое он получил и сам) способно исправить человека от многих недостатков, укореняющихся в будущем [Гурджиев 2009c, c. 32-36]. В этой книге Гурджиев подчеркивал необычность содержания, его исключительность, отличающуюся от всех предшествовавших книг. Это достигалось средствами как формы - книга была написана на русско-армянском языке, её можно было читать, не разрезая страниц [Гурджиев, 2004, с. 13, 17], - так и содержания: книга была написана в жанре космической фантастики, сюжет выходил за события на Земле, в работе развивалось новое гурджиевское учение, синтезирующее все достижения духовной жизни человечества в историческом контексте и в привязке к общекосмическим явлениям, в самой книге употреблялись новые слова, придуманные Гурджиевым на основе корней из разных языков (кундабуфер - искажающий орган, хаснамусс - эгоистичный человек, раскуарно смерть, психея - душа, тело кесджан - астральное тело, парткдолг-обязанности - космический долг и др.), а также общеупотребительные термины в непривычном смысле (присутствие - бытие человека; кристаллизация - укоренение в характере человека определенных свойств; возраст ответственности - совершеннолетие, планетарное тело - физическое тело и др.).

Главным героем также взят не традиционный персонаж, а известный в авраамических религиях демон Вельзевул, считающийся по уму на втором месте после Люцифера, повелитель ложных богов [Бровко, 2019, с. 15-16]. Гурджиев вульгарно объясняет выбор персонажа стремлением «подмазать» этому демону для успеха своего произведения, а также выбор связан со стремлением автора отличаться от общепринятых норм [Гурджиев, 2004, с. 28-29].

Основной сюжет книги состоит в том, что Вселенная является управляемой по гармоничным законам, а также обитаемой и населенной разумными сущностями, высшие из которых относятся к категории трехмозговых существ, т. е., имеющих три мозговых центра (головной - разум, спинной - эмоции, солнечное сплетение - душа) [Гурджиев, 2004, c. 91], что позволяет им самосовершенствоваться и сливаться с Абсолютом (Солнце Абсолют). Вселенная управляется единым Творцом (его Бесконечность Вселюбящий, Бесконечно-Милосердный и Абсолютно-Справедливый Творец), а также Высочайшими Наисвященнейшими Общекосмическими Индивидуумами, носящими названия по христианской иерархии (Святой Архангел, Святой Архисерафим и т. д.). В основе существования Вселенной лежат законы «семи» (теория 7 ключевых элементов в основе всего: звук, цвет и т. д.), по которым она устроена, и «трех», по которым она развивается (совпадают с законами диалектики). Главным элементом преобразования является Вездесущий Активный Элемент (Окиданох), лежащий в основе всех процессов, согласно Великой Природе. В основе Вселенной лежит её гармоничное устройство, за которым следят Архангелы, поддерживающие везде гармонию. Все космические сущности, которые не могут сразу достичь перерождения и слияния с Солнцем Абсолютом, отправляются на самую святую 
планету «Чистилище», где в райских условиях очищаются от своих недостатков и достигают необходимого совершенства. Противником и основным злом Вселенной является Безжалостный Геропас - Время, выступающее как неотвратимый факт.

Вельзевул является представителем одной из высших космических трехмозговых рас, визуально выглядящей как традиционные черти (с рогами, копытами и хвостом) [Гурджиев, 2004, с. 41]. В молодости за некие просчеты, приведшие к угрозе гармонии Вселенной, он был сослан в отдаленную Солнечную систему Орс, в изгнание, там находилась и планета Земля [Гурджиев, 2004, с. 33-34]. В процессе длительного изгнания он наблюдал за событиями на Земле, сам вместе со своими соплеменниками обитая на планете Марс. Впоследствии он получил прощение от Творца и смог вернуться на родную планету. Все повествование связано с возвращением Вельзевула на космическом корабле на свою планету, дабы скоротать путешествие, рассказывающего своему внуку Хуссейну об истории и жизни на одной из планет - Земле, которая была населена трехмозговыми живыми существами. Кроме Земли, разумными существами были населены и другие планеты: упоминаются Марс (они длинное тело с жиром, глаза навыкате, крылья и маленькие ноги с когтями), а также Сатурн (они были внешне похожи на ворон) и Луна (существа напоминали муравьев и были очень трудолюбивы) [Гурджиев, 2004, с. 40, 58-59]. На Сатурн автор переносит успешные алхимические опыты по получению «философского камня»- золота из преобразования различных веществ [Гурджиев, 2004, с. 107].

Согласно рассказу Вельзевула, жизнь на Земле изначально была искажена. В момент формирования Земли произошла ошибка в расчетах, в результате чего Земля столкнулась с планетой Кондур. Произошла катастрофа, из-за чего от Земли отделились планеты Луна и Анулис. Для поддержания их функционирования и сохранения гармонии в Космосе на Земле появились трехмозговые существа, целью жизни которых было выделять энергию на существование двух отколовшихся планет, то есть их жизнь не имела самостоятельной цели [Гурджиев, 2004, с. 53-57]. Зависимость от Луны Гурджиев не одобряет, в одной из своих бесед он указывает, что человек должен преодолеть её в своем самосовершенствовании [Гурджиев, 2009с, с. 122; Гурджиев, 2018a, с. 16].

Дабы люди не взбунтовались и не отказались из принципа поддерживать свою жизнь из-за этих причин, Архангелами был в их организм встроен некий орган кундабуфер, изменявший восприятие реальности ими и сильно исказивший их природу [Гурджиев, 2004, с. 57-59]. Это привело к тому, что люди оказались неполноценными трехмозговыми существами, утратили знания о космических законах и стали жить эгоистично, охваченные различными страстями, совершая вещи, нарушавшие космическую гармонию (жертвоприношения, убийства, различные преступления), что не давало возможности их душам после смерти (Раскуарно) достичь Абсолюта и нарушало космические процессы, так как выделяемая при жизнедеятельности живых существ энергия идет в Космос на обеспечение общекосмических (трогоавтоэгократических) процессов. Из-за искажения природы и постоянных войн и уничтожений других живых существ время жизни людей резко сократилось, в частности, 1-й год расы Вельзевула равнялся 389 годам человеческой эры [Гурджиев, 2004, с. 89].

В начале существовал материк Атлантида - наиболее развитая цивилизация, где представители расы Вельзевула жили рядом с людьми и пытались их исправить. Но после локальной внутрипланетарной катастрофы Атлантида утонула. После гибели Атлантиды раса Вельзевула уже не жила на Земле. Все люди, за исключением некоторых ученых мудрецов, погибли [Гурджиев, 2004, с. 70-74, 109-111].

По итогам этого Архангелы решили удалить кундабуфер из людей, но его последствия продолжали негативно на них влиять. В итоге на Землю посылались различные представители высших космических существ, чтобы научить людей правильной жизни, став основателями различных религий (Будда, Моисей, Иисус Христос, Лама, Магомед). Но ничего достичь не удалось. Религии Гурджиевым высмеиваются как искажавшие пер- 
воначальные учения высших индивидуумов [Гурджиев, 2004, с. 142-147, 152-156, 392-399].

Сам Вельзевул спускался на Землю 6 раз в разные эпохи. В 1-й раз он посещал Атлантиду, во 2-й и 3-й - пустыни Каракум, пустыни Гоби и Индии, где в древности существовали развитые цивилизации, дабы отучить людей от человеческих и животных жертвоприношений, нарушающих космическую гармонию, так как жизнь каждого существа важна. В 4-й раз - Древний Египет для отлова обезьян на опыты, где осели ученые Атлантиды и сохранили её учение. Особо высокого уровня достигли архитектура, математика, медицина, особенно в области бальзамирования и мумификации, а также астрология, которая объединяла мир космоса с человеческой жизнью [Гурджиев, 2004, с. 69-70, 108-150, 159-185]. В 5-й раз Вельзевул посещал Вавилон, являвшийся центром наук и образованности. В Вавилоне был период жарких дискуссий в области политики и человеческой природы души. Именно в Вавилоне развивалось учение о душе, существовании Рая и Ада, а также атеистическое учение.

Также в этот период на Землю спустился наиболее великий из космических учителей Ашиеша Шиемаш, который разработал учение, позволяющее людям, преодолев последствия органа куднабуфер, достичь нормального состояния для трехмозгового существа путем воздействия на внутреннюю совесть, которая дремлет в подсознании человека. Ашиеша Шиемаш положил начало. Учение передавалось путем легоминизма, предполагавшего интуитивное воздействие на человека с помощью символов и видов искусства учения. Однако в процессе дальнейшего существования искусство исказилось и стало «вещью в себе», то есть искусством ради искусства, направленным на низменные удовольствия публики [Гурджиев, 2004, с. 185-225, 257-298]. Но труды Ашиеша Шиемаша были уничтожены неким вавилонским великим ученым, ставшим хаснамуссом. Хаснамусс - это наиболее мерзкий, по Гурджиеву, тип человека, который отказался от своего космического долга и живёт для себя. Этот хаснамусский ученый разработал индивидуалистическое политическое учение о свободе личности, отрицавшее коллективизм и долг (демократические учения) [Гурджиев, 2004, с. 225-237], что может косвенно указывать, что Ашиеша Шиемаш был Зороастром, чьи труды были уничтожены македонским завоевателем.

Также Вельзевул был осведомлен о первых европейских цивилизациях - античных древнегреческой и древнеримской. Их он презирал, считая очень примитивными. Греки, по его мнению, были рыбаками, которые для развлечения занимались выдумыванием пустых наук и разговоров ни о чем, легших в основу европейской рационалистической науки. Римляне были пастухами, которые ради развлечения устраивали оргии как с мужчинами, так и с женщинами, а затем под влиянием греков выдумали пустую науку римское право [Гурджиев, 2004, с. 237-245].

В 6-й раз Вельзевул оказался в XIX веке, который уже был веком деградации по сравнению с древними временами. Вельзевул применительно к этому времени выступает как персонализация самого Гурджиева. Он также владеет 18 языками и занимается гипнозом как методом врачевания [Гурджиев, 2004, с. 303, 318]. Сохраненные остатки древней традиции Вельзевул обнаруживает в Бухаре, встретив там в монастыре одного из великих учёных дервишей, который изучал природу звука и разработал устройство для измерения колебаний. В этой части работы Гурджиевым рассматривается его музыкальная теория, согласно которой восточная музыкальная структура была гораздо более передовой, фиксирующей больше оттенков звуков, чем западная, так как музыкальный слух восточных народов гораздо тоньше [Гурджиев, 2004, с. 456-513].

В Азии Вельзевулу импонировали чайханы, где можно было выпить чай и заняться обсуждением проблем. Но он критикует современные страны: китайский Туркестан за распространение гашиша, русский Туркестан и Россию - за употребление водки и алкоголизм [Гурджиев, 2004, с. 331-332]. Население России он критикует, воспринимая его как 
«ни туда, ни сюда»: стремясь быть «павлинами» (европейцы), но имея природу «воронов» (азиаты), русские превратились в «индюков», отказавшись от собственных полезных традиций (баня, чистка зубов жеванием смол) в угоду европейской моде. Также критикуется современная практика православия, в которой есть пренебрежение строгим соблюдением постов [Гурджиев, 2004, с. 257, 340-342, 366, 567-568, 571]. Европейские страны подвергаются еще большей критике: Германия - за развитие пустых наук, которые не являются науками, так как не имеют ничего духовного, и изобретение вредных химических веществ: отравляющих газов, наркотиков, красителей, медицинских препаратов [Гурджиев, 2004, с. 245-257, 373-374]; Англия - за изобретение металлических орудий, несущих смерть (ружья, пули и т. п.) и спорт, приводящий человека к состоянию калеки [Гурджиев, 2004, с. 245-257, 373-374]; Францию - за развращенность нравов в столице Париже [Гурджиев, 2004, с. 375-392]; США - за культ доллара и лживую рекламу [Гурджиев, 2004, с. 514-528], и ряд других стран. Критика народов переходит в критику современных достижений европейской цивилизации. Он обрушивается на людей за использование консервов, за применение модифицированных плодов в пищу, за ватерклозеты, моду, стрижку и суфражизм женщин, неправильное воспитание, половую распущенность, измены и проституцию, приводящие к болезням. В пример ставятся восточные общества [Гурджиев, 2004, с. 390-391, 528-560, 572-574, 577-584].

Также в лице Вельзевула Гурджиев критикует и современные политические системы: бюрократию, плутократию, аристократию и демократию [Гурджиев, 2004, с. 603-605]. Отдельно он останавливается на феномене большевизма, связывая его, как и все народные восстания, с космическими процессами, направленными на повышение активности солнца и негативно воздействующими на человека. В итоге люди впадают как бы в сумасшествие и начинают испытывать зависть к вышестоящим, что приводит к восстанию [Гурджиев, 2004, с. 357-358]. Отдельно он останавливается на войне, которая также связывается им с природными процессами. Люди испытывают потребность в самоуничтожении друг друга, что становится следствием органа кундабуфер и природных процессов. И-за этого войны не прекратятся, а международные организации ничего не добьются, в том числе и Лига наций [Гурджиев, 2004, с. 588-594, 613-622].

Критикует Вельзевул и учение о морали и разделении добра и зла на Земле. По его мнению, нет понятия «злая сила» или «добрая сила». Все зависит от самого человека. А тот, кто разработал эти понятия как внешние, должен был бы отбывать наказание на самой дальней планете [Гурджиев, 2004, с. 622-634]. Попутно Вельзевул высмеивает представления людей о своей расе среди них как злой силе, присутствующей незримо [Гурджиев, 2004, с. 635-636]. Здесь виден намек на высмеивание авраамических религий Гурджиевым, что является одним из оснований выбора именно Вельзевула в качестве главного действующего лица.

Но одной из главных вещей современности, которую Гурджиев подверг критике, является электричество. Использование электричества ради личных эгоистичных людских нужд приводит к дисгармонии в Космосе, так как уничтожает священное вещество Окиданох, являющееся основой всех космических процессов. На Марсе разумные существа стали испытывать трудности с саморазвитием, на Сатурне стали плохо себя чувствовать по этой причине, на Земле из-за него жизнь человека укорочена [Гурджиев, 2004, c. 637-646].

В конце Вельзевул и его внук вместе со всем экипажем, слугами прибывают на свою планету, и там Вельзевул перерождается. За свою праведную жизнь в изгнании и помощь и заботу о трехмозговых существах Земли он удостаивается одного из высших титулов святости, проявлявшегося в том, что у него вырастают 5 рогов на голове. Уже в статусе святого Вельзевул находит решение для человечества Земли, а именно: внедрить в их организм орган, осознающий неотвратимость смерти. Это позволит исправить их природу [Гурджиев, 2004, с. 653-659]. 
В целом «Рассказы Вельзевула» являются довольно всеохватывающей фантастикой с разработанной структурой Вселенной, интересным сюжетом и личностями. Но в то же время Гурджиев делает много псевдонаучных построений, в духе традиционализма оценивая современную рациональную европейскую науку. Очень примитивна критика естественнонаучных знаний с позиции традиционализма, а выводы, зачастую частные и примитивные, часто содержат невежественные заблуждения, например, происхождение обезьян от людей, или статус Луны как планеты, или перечисление только галогенов как базовых для природы веществ. Сюда же относится отрицание важности технического прогресса. Также в его работе показан псевдоисторический контекст, все древние цивилизации, которые он рассматривает, вымышлены, как и события в них. Практически все исторические персоналии, за исключением, пожалуй, религиозных деятелей, Пифагора, Александра Македонского, Бисмарка, Николая II, являются придуманными. Равно и эры, в которые происходили «события», также разработаны Гурджиевым, а времяисчисление ведется по «космической» эре [Гурджиев, 2004, с. 34].

В более поздних вариантах «Рассказов Вельзевула» добавляется дополнение в виде нескольких лекций, где Гурджиев подводит итоги своим размышлениям. Сначала рассматриваются человеческие составляющие ум, чувства и тело как кучер, лошадь и повозка. Суть самосовершенствования - чтобы все части работали слаженно, как и сам экипаж. Затем в лекции «Две реки» Гурджиев проводит параллель человеческого развития с рекой, разбивающейся на два потока: один течет спокойно и дальше, другой низвергается и скрывается в трещине земли. Так и человеческая жизнь после достижения совершеннолетия может повернуть в любую сторону. Цель человека - перейти в правильный «поток», даже если изначально он отправился в неправильный, путем упорной работы над собой. Отдельно эти лекции издаются в работе под названием «Закономерное разнообразие проявлений человеческой индивидуальности» [Гурджиев, 1999, с. 974-1017].

Помимо «Рассказов Вельзевула» и примыкающих к нему лекций под названием «Закономерное разнообразие проявлений человеческой индивидуальности» у Гурджиева есть еще ряд произведений. Это автобиографическое сочинение «Встречи с замечательными людьми», представленное в виде 9 частей, посвященных тем людям, которые оказали наибольшее влияние на духовное становление автора: отцу, учителям и друзьям, построенное таким образом, что в хронологическом порядке охватывает детство, юность и молодость Гурджиева. В дополнении дается 10 часть, посвященная финансовому вопросу, где Гурджиев в Нью-Йорке в 1924 г. рассказывает американским ученикам, как зарабатывал на жизнь в процессе своей жизни. Эта лекция была прочитана с целью просить денег на Институт. В книге есть послесловие, из которого можно предположить, что Гурджиев завершил книгу в 1931 г., находясь в Нью-Йорке, так как он сообщает об аварии и том, что 6 лет работает над книгами [Гурджиев, 2018b].

Большинство остальных работ - это лекции Гурджиева ученикам с автобиографическими вставками и зарисовками. Многие лекции были собраны и изданы в последующем учениками Гурджиева.

Работа «Вестник грядущего добра» является рекламной брошюрой, выпущенной в 1933 году в Париже, где излагается суть работы Института гармонического развития, а также представляет результаты деятельности Гурджиева. Эта книга провалилась [Гурджиев, 2008c].

В работе «Жизнь реальна только тогда, когда "Я есть“», которую Гурджиев написал в 1934 г., излагаются его 5 бесед с учениками в Северной Америке, в Нью-Йорке, проведенных в 1930-1932 гг. В этих беседах, носящих автобиографический характер, Гурджиев рассказывает американским ученикам о своей деятельности, начиная от основания Института гармонического развития в России до современного времени. Особое внимание он уделяет периоду с первой поездки в Америку в 1924 г. до времени проведения беседы [Гурджиев, 2014]. 
В работе «Взгляды из реального мира» Гурджиев собирает лекции и беседы с учениками, непосредственно излагающие его учение, где он объясняет ученикам, как правильно работать над собой и достигать саморазвития по четвертому пути. Здесь затрагиваются проблемы самонаблюдения, воли, добровольного страдания, сна и бодрствования, актерского мастерства, музыки, Луны, путей самосовершенствования в различных религиях, магии, строения человеческого тела и души, внешним влияниям, связи человека с космосом, свойствам характера. Эти лекции и беседы относятся к прочитанным в 1923 г. в Германии и Франции, а также прочитанным в 1924 и 1929-1930 гг. в США. Также есть лекция, прочитанная в Ессентуках в 1918 г. [Гурджиев, 2018а].

Другое издание этих лекций - «Человек - это многосложное существо», где учение Гурджиева изложено более системно, там сделаны дополнения по отношению к первому изданию, добавлено несколько лекций по другим темам: о человеке как машине, о вреде развития только отдельных сфер в человеке, о методах Института в сравнении с религиозными практиками, о воспитании детей, о мыслительном центре, о сущности человеческой личности и работе над собой, упражнениях, практикуемых в Институте, в том числе упражнении «стоп», контроле над дыханием, искусстве, Боге, эволюции и пище, кристаллизации, путях самосовершенствования и четвертом пути, беспристрастности [Гурджиев, 2009c].

В работе «Беседы с учениками 1941-1944 гг.» даны беседы Гуржиева с учениками по конкретной практике их саморазвития, где он спрашивает, какие результаты достигнуты в ходе упражнений, дает им наставления и советы по преодолению возникших трудностей [Гурджиев, 2008b]. Сборник состоит из 32 бесед, которые состоялись в период с 1941 по 1944 гг. во Франции, в Париже, но также есть беседы 1946 г. Эта книга была издана учениками Гурджиева впоследствии. Более сокращенная версия бесед - «Восемь встреч в Париже» [Гурджиев, 2009а].

Также можно отметить несколько отдельных лекций, изданных учениками Гурджиева. В лекции «О символизме» раскрывается проблема легоминизма как передачи знаний с помощью символов, которые можно расшифровать даже при утрате языка. Тут внимание уделяется искусству как средству передачи знаний, прежде всего, музыкальному. Различные геометрические фигуры отражают закономерности Вселенной. Одной из главных фигур является эннеаграмма. Инициация связана с постижением тайного смысла символов [Гурджиев, 2008d]. В лекции «48 упражнений» дана последовательность упражнений, необходимых для саморазвития [Гурджиев, 2009а]. В лекции «Последний час жизни» Гурджиев подчеркивает ценность этого времени и учит, как правильно этот час провести, - максимально полно и продуктивно приготовиться к переходу из одного состояния в иное [Гурджиев, 2009b]. В беседе «Вопросы и ответы», издаваемой в сборнике воспоминаний учеников Гурджиева «Гурджиев. Эссе и размышления о Человеке и его Учении», Гурджиев учит своих учеников, как надо правильно работать над собой [Гурджиев, 2002, c. 14-30].

Помимо философских работ у Гурджиева есть пьеса «Битва магов» в 5 актах, которая связана с музыкально-танцевальной практикой его института, что-то вроде сценария балета. По сюжету этой пьесы в некоем крупном центре Средней Азии живет молодая девушка - ученица Светлого мага, в которую случайно влюбляется молодой аристократ, 32 лет, ищущий себя. Не в силах привлечь девушку к себе обычными средствами, он обращается к колдунье, которая отводит его к Черному магу. За большие деньги Черный маг вместе со своими учениками привораживает девушку. Но благодаря тому, что Белый маг вовремя узнал об этом, он смог со своими учениками расколдовать свою лучшую ученицу, победив Черного чародея, и найти виновных [Gurjieff, 1953].

Таким образом, подводя итоги исследования жизни и деятельности философа 1-й пол. XX в. Георгия Гурджиева, можно сделать несколько выводов. Гурджиев был представителем русского направления интегрального традиционализма, его учение включало 
все сущностные черты этого философского направления: критику современного европейского общества, науки и культуры, пропаганду возвращения к истокам путем самосовершенствования, для чего им была разработана оригинальная методика «Четвертого пути», включавшая обширную практику работы над собой, а также гипноз как средство этой работы. В отличие от европейских традиционалистов Гурджиев де-факто не опирался на какую-либо религиозную систему, подвергая критике их все, хотя в своем учении привлекал практики восточных монашеских течений, главным образом среднеазиатских суфиев и факиров, но также индийских и тибетских йогов, православных монахов.

Национально-русские особенности его учения состояли в том, что оно воспроизводило многие идеи русского космизма в плане развития человека как части разумного Космоса, кроме того, отказался от абсолютного отвержения христианской религиозной системы, называя свое учение эзотерическо-христианским, учитывая большой потенциал православной религии, в отличие от западноевропейских традиционалистов. Также, так как он был выходцем с Кавказа и греко-армянином по происхождению, находясь на пересечении различных восточных культур, он интегрировал их в своем учении. В основе его трудов лежал интерес к среднеазиатской суфийской религиозной практике, которая обычно остается вне поля зрения западноевропейских философов. Следует отметить, что учение Гурджиева ориентировалось на псевдоисторическую традицию, которую, весьма вероятно, он придумал сам. Он был мистификатор и создавал тот образ себя как Учителя, который позволил бы ему наиболее эффективно реализовать идеи своего учения на практике. В то же время его представления о мире были вульгарно-народными, зачастую опираясь на закавказский и среднеазиатский фольклор.

В основе его концепции лежало представление о гармоничном развитии человека как в физическом (поддержание физического здоровья организма), так и духовном (эмоции, ум, воля) плане. Его представления состояли в том, что человек - это часть Вселенной, управляемой Единым Творцом, и живет по тем же законам. Но земной человек имеет искаженную сущность из-за внешней обстановки, направленной на удовлетворение низменных потребностей, в которых человек забыл о своем истинном предназначении.

Bce земные обстоятельства (политическое устройство, наука, социальноэкономическое положение) Гурджиев презирал. Кроме того, если западноевропейские традиционалисты зачастую были теоретиками, то Гурджиев был практиком, основавшим собственную школу - «Институт гармонического развития», - где и реализовывал свои идеи. Первым из всех философов-традиционалистов он уделил внимание воплощению своего учения на практике и впервые показал финансовые проблемы. Презрение Гурджиева к европейской цивилизации выражалось в сугубо материалистическом подходе к своим ученикам. Тем не менее они его любили и ценили, развивая и поддерживая его учение в дальнейшем. Идеи Гурджиева живут и пользуются спросом до сих пор.

\section{Список литературы}

1. Алексахин В. 2003. Биография Георгия Ивановича Гурджиева. Сайт Lib.Ru: Георгий Иванович Гурджиев. URL: http://lib.ru/URIKOVA/GURDZHIEW/gurdbio.txt (дата обращения 01.02.2021).

2. Гордлевский В.А. (изд.). 1957. Анекдоты о Ходже Насреддине. М., Изд-во Восточной литературы, 275.

3. Беннетт Д.Г. 2006. Свидетель, или История поиска. М., Гаятри, 433.

4. Бровко В.П. 2019. Георгий Гурджиев и его Вельзевул. М., Литрес: Самиздат, 390.

5. Вандерхилл Э. 1996. Гурджиев. В: Мистики ХХ в. Энциклопедия. М., Миф; Локид: $164-180$.

6. Греков И.М. 2013а. Идея работы в духовном опыте школы «Четвёртого пути» Г.И. Гурджиева. В: Гуманитарные и социальные науки. 1: 141-151.

7. Греков И.М. 2013b. Развитие и интерпретация идей Г.И. Гурджиева в работах его последователей. В: Гуманитарные и социально-экономические науки. 1 (68): 14-19. 
8. Греков И.М. 2013c. Сознательная эволюция человека в философско-религиозном учении Г.И. Гурджиева. Дисс... канд. филос. наук. Ростов-на-Дону, 146.

9. Гурджиев Г.И. 2002. Вопросы и ответы. В: Гурджиев. Эссе и размышления о Человеке и его Учении (сборник). М., Страйклайт: 14-30.

10. Гурджиев Г.И. 2004. Все и вся. Объективно-беспристрастная критика жизни человека, или Рассказы Вельзевула своему внуку. М., Эксмо, 880 .

11. Гурджиев Г.И. 2008а. 48 упражнений. В: Сайт Gurdjieff Club. URL: https://gurdjieffclub.com/48-uprazhnenii/ (дата обращения 01.02.2021).

12. Гурджиев Г.И. 2008b. Беседы с учениками. Париж 1941-1944. В: Сайт Gurdjieff Club. URL: https://gurdjieffclub.com/knigi-besedy-s-uchenikam/ (дата обращения 01.02.2021).

13. Гурджиев Г.И. 2008c. Вестник грядущего добра. В: Сайт Gurdjieff Club. URL: https://gurdjieffclub.com/knigi-vestnik-grjadushchego-dobra/ (дата обращения 01.02.2021).

14. Гурджиев Г.И. 2008d. Лекция о символизме (эннеаграмма). В: Сайт Gurdjieff Club. URL: http://www.endlesssearch.co.uk/philo_enneagramtalk_russian.htm (дата обращения 01.02.2021).

15. Гурджиев Г.И. 2009а. Восемь встреч в Париже. В: Сайт «Четвертый путь. Гурджиев Успенский - Суфизм». URL: http://www.fway.org/onlinelib/48-2009-02-10-15-05-46/180-2009-02-1015-16-02.html (дата обращения 01.02.2021).

16. Гурджиев Г.И. 2009b. Последний час жизни. В: Сайт «Четвертый путь. Гурджиев Успенский - Суфизм». URL: http://www.fway.org/onlinelib/47-psl/177-2009-02-10-14-58-30.html (дата обращения 01.02.2021).

17. Гурджиев Г.И. 2009с. Человек - это многосложное существо. В: Сайт «Четвертый путь. Гурджиев - Успенский - Суфизм». URL: http://fway.org/onlinelib/64--q-q/323--q-q-.html (дата обращения 01.02.2021).

18. Гурджиев Г.И. 2014. Жизнь реальна только тогда, когда «Я есть». М., Энигма, 240.

19. Гурджиев Г.И. 2018а. Взгляды из реального мира. М., Энигма, 376.

20. Гурджиев Г.И. 2018b. Встречи с замечательными людьми. М., Энигма, 368.

21. Гурджиев Г.И. 1999. Закономерное разнообразие проявлений человеческой индивидуальности. В: Гурджиев Г.И. Беседы Вельзевула со своим внуком. Минск, Харвест: 974-1017.

22. Клостре С. 2002. Десерт. В: Гурджиев. Эссе и размышления о Человеке и его Учении (сборник). М., Страйклайт: 167-173.

23. Кравченко В.В. 1997. Мистицизм в русской философской мысли XIX - начала XX веков. М., Издатцентр, 280.

24. Кравченко В.В. 2020. Русский мистицизм как образ «другого» для западного эзотеризма. В: Вестник Тверского государственного университета. Сер. Философия. 3 (53): 174-187.

25. Куракина О.Д. 2014. Русский космизм - мировоззрение русской цивилизации. В: Булгаковские чтения. 8: 6-12.

26. Кучеренко В.А. 2005. Учение о человеке Г.И. Гурджиева в контексте духовных исканий современности. Дисс... канд. филос. наук. Ростов-на-Дону, 141.

27. Лемешев О. (диак.). 2019. Мистическое учение о «совести» в оккультной концепции «Четвёртого пути». В: Вопросы богословия. Т. 2. 2: 70-87.

28. Лунин Б.В. 1958. Из истории русского востоковедения и археологии в Туркестане. Туркестанский кружок любителей археологии (1895-1917). Ташкент, Изд-во АН Узбекской ССР, 320.

29. Нежинский И.В. 2009. Эзотерическое христианство Георгия Гурджиева. В: Сайт «Четвертый путь. Гурджиев - Успенский - Суфизм». URL: http://fway.org/articles/261-2009-03-1320-35-10.html (дата обращения 01.02.2021).

30. Орлов И.О. 2006. Научная революция конца XIX - начала XX века. В: Философия науки. 1 (28): 130-148.

31. Пильчинова Е.В. 2014. Научно-техническая революция как основной фактор развития производительных сил: исторический обзор. В: Вестник Бурятского государственного университета. 2: 22-25.

32. Питанов В.Ю. 2016. Георгий Гурджиев - оккультист или христианин? В: Персональный сайт Питанова Виталия Юрьевича. Психология, сравнительное религиоведение, апологетика. URL: http://pitanov.info/georgiy-gurdzhiev-okkultist-ili-hristianin (дата обращения 01.02.2021).

33. Полонская И.Н. 2005. Философские принципы традиционализма. В: Научная мысль Кавказа. 4: 30-36. 
34. Ровнер А.И. 2002. Гурджиев и Успенский. М., София: Гелиос, 509.

35. Свиридовская Н.Д. 2014. Фома Гартман: неизвестный композитор круга Танеева и Рахманинова. В: Научный вестник Московской консерватории. 1: 68-85.

36. Седжвик М. 2014. Наперекор современному миру. Традиционализм и тайная интеллектуальная история XX века. М., Новое литературное обозрение, 536.

37. Успенский П.Д. 2014. В поисках чудесного. М., Энигма, 488.

38. Уэлш У.Д. 2002. Воспоминания. В: Гурджиев. Эссе и размышления о Человеке и его Учении (сборник). М., Страйклайт: 145-166.

39. Филиппович А.В. 2014. Историософия интегрального традиционализма. В: Антро. 2(15): 51-62.

40. Холодов М., Молотов О. 2010. Традиция и традиционализм: о терминах и их содержании. В: Полюс. 1: 4-9.

41. Baker R. 2000. No Harem. Gurdjieff and the Women of The Rope. In: Gurdjieff International Review. URL: https://www.gurdjieff.org/G.1-2.htm (дата обращения 01.02.2021).

42. Gurjieff G.I. 1953. Scenario of the Ballet «The Struggle of the Magicians». Capetown, South Africa, The Stourton Press, 44.

43. Taylor P.B. 1998. The Shadows of Heaven: Gurdjieff and Toomer. Newburyport, Red Wheel Weiser, 272.

\section{References}

1. Aleksahin V. 2003. Biografiya Georgiya Ivanovicha Gurdzhieva [Biography of George Ivanovich Gurdjieff]. In: Sajt Lib.Ru: Georgij Ivanovich Gurdzhiev [Lib.Ru website: Georgy Ivanovich Gurdjieff]. Available at: http://lib.ru/URIKOVA/GURDZHIEW/gurdbio.txt (accessed 1 February 2021) (in Russian).

2. Bennett D.G. 2006. Svidetel', ili istoriya poiska [Witness, or search history]. Moscow, Gayatri, 433.

3. Brovko V.P. 2019. Georgij Gurdzhiev i ego Vel'zevul [George Gurdjieff and his Beelzebub]. Moscow, Litres: Samizdat, 390.

4. Filippovich A.V. 2014. Istoriosofiya integral'nogo tradicionalizma [Historiosophy of integral traditionalism]. In: Antro [Antro]. 2 (15): 51-62.

5. Gordlevskij V.A. (ed.). 1957. Anekdoty o Hodzhe Nasreddine [Jokes about Hodja Nasreddin]. Moscow, Izd-vo Vostochnoj literatury, 275.

6. Grekov I.M. 2013a. Ideya raboty v duhovnom opyte shkoly «Chetvyortogo puti» G.I. Gurdzhieva [The idea of working in the spiritual experience of the «Fourth Way» school by G.I. Gurdjieff]. In: Gumanitarnye i social'nye nauki [Humanities and social sciences]. 1: 141-151.

7. Grekov I.M. 2013b. Razvitie i interpretaciya idej G.I. Gurdzhieva v rabotah ego posledovatelej [Development and interpretation of G.I. Gurdjieff in the works of his followers]. In: Gumanitarnye i social'no-ekonomicheskie nauki [Humanities and socio-economic sciences]. 1 (68): 14-19.

8. Grekov I.M. 2013c. Soznatel'naya evolyuciya cheloveka v filosofsko-religioznom uchenii G.I. Gurdzhieva [Conscious human evolution in the philosophical and religious teaching of G.I. Gurdjieff]. Diss... Cand. Philos. sciences (PhD). Rostov-na-Donu, 146.

9. Gurdzhiev G.I. 1999. Zakonomernoe raznoobrazie proyavlenij chelovecheskoj individual'nosti [The natural variety of manifestations of human individuality]. In: Gurdzhiev G.I. Besedy Vel'zevula so svoim vnukom [Gurdjieff G.I. Beelzebub's conversations with his grandson]. Minsk, Harvest: $974-1017$.

10. Gurdzhiev G.I. 2002. Voprosy i otvety [Questions and answers]. In: Gurdzhiev. Esse i razmyshleniya o Cheloveke i ego Uchenii [Gurdjieff. Essays and Reflections on Man and His Teachings] (collection). Moscow, Strajklajt: 14-30.

11. Gurdzhiev G.I. 2004. Vse i vsya. Ob"ektivno-bespristrastnaya kritika zhizni cheloveka, ili Rasskazy Vel'zevula svoemu vnuku [Everything and everyone. About an objectively impartial criticism of a person's life, or Beelzebub's Tales to his grandson]. Moscow, Eksmo, 880.

12. Gurdzhiev G.I. 2008a. 48 uprazhnenij [48 exercises]. In: Sajt Gurdjieff Club [Gurdjieff Club website]. Available at: https://gurdjieffclub.com/48-uprazhnenii/ (accessed 1 February 2021) (in Russian). 
13. Gurdzhiev G.I. 2008b. Besedy s uchenikami. Parizh 1941-1944 [Conversations with students. Paris 1941-1944]. In: Sajt Gurdjieff Club [Gurdjieff Club website]. Available at: https://gurdjieffclub.com/knigi-besedy-s-uchenikam/ (accessed 1 February 2021) (in Russian).

14. Gurdzhiev G.I. 2008c. Vestnik gryadushchego dobra [Herald of good things to come]. In: Sajt Gurdjieff Club [Gurdjieff Club website]. Available at: https://gurdjieffclub.com/knigi-vestnikgrjadushchego-dobra/ (accessed 1 February 2021) (in Russian).

15. Gurdzhiev G.I. 2008d. Lekciya o simvolizme (enneagramma) [Lecture on Symbolism (Enneagram)]. In: Sajt Gurdjieff Club [Gurdjieff Club website]. Available at: http://www.endlesssearch.co.uk/philo_enneagramtalk_russian.htm (accessed 1 February 2021) (in Russian).

16. Gurdzhiev G.I. 2009a. Vosem' vstrech v Parizhe [Eight meetings in Paris]. In: Sajt «Chetvertyj put'. Gurdzhiev - Uspenskij - Sufizm» [Website «The Fourth Way. Gurdjieff - Uspensky Sufism»]. Available at: http://www.fway.org/onlinelib/48-2009-02-10-15-05-46/180-2009-02-10-15-1602.html (accessed 1 February 2021) (in Russian).

17. Gurdzhiev G.I. 2009b. Poslednij chas zhizni [The last hour of life]. In: Sajt «Chetvertyj put'. Gurdzhiev - Uspenskij - Sufizm» [Website «The Fourth Way. Gurdjieff - Uspensky - Sufism»]. Available at: http://www.fway.org/onlinelib/47-psl/177-2009-02-10-14-58-30.html (accessed 1 February 2021) (in Russian).

18. Gurdzhiev G.I. 2009s. Chelovek - eto mnogoslozhnoe sushchestvo [Man is a polysyllabic creature]. In: Sajt «Chetvertyj put'. Gurdzhiev - Uspenskij - Sufizm» [Website «The Fourth Way. Gurdjieff - Uspensky - Sufism»]. Available at: http://fway.org/onlinelib/64--q-q/323--q-q-.html (accessed 1 February 2021) (in Russian).

19. Gurdzhiev G.I. 2014. Zhizn' real'na tol'ko togda, kogda «Ya est'» [Life is real only when «I am»]. Moscow, Enigma, 240.

20. Gurdzhiev G.I. 2018a. Vzglyady iz real'nogo mira [Views from the real world]. Moscow, Enigma, 376.

21. Gurdzhiev G.I. 2018b. Vstrechi s zamechatel'nymi lyud'mi [Meeting wonderful people]. Moscow: Enigma, 368.

22. Holodov M., Molotov O. 2010. Tradiciya i tradicionalizm: o terminah i ih soderzhanii [Tradition and traditionalism: on terms and their content]. In: Polyus [Pole]. 1: 4-9.

23. Klostre S. 2002. Desert [Dessert]. In: Gurdzhiev. Esse i razmyshleniya o Cheloveke i ego Uchenii [Gurdjieff. Essays and Reflections on Man and His Teachings] (collection). Moscow, Strajklajt: $167-173$.

24. Kravchenko V.V. 1997. Misticizm v russkoj filosofskoj mysli XIX - nachala XX vekov [Mysticism in Russian philosophical thought of the XX - early XX centuries]. Moscow, Izdatcentr, 280.

25. Kravchenko V.V. 2020. Russkij misticizm kak obraz «drugogo» dlya zapadnogo ezoterizma [Russian mysticism as an image of the «other» for Western esotericism]. In: Vestnik Tverskogo gosudarstvennogo universiteta [Bulletin of Tver State University]. Ser. Philosophy. 3 (53): 174-187.

26. Kucherenko V.A. 2005. Uchenie o cheloveke G.I. Gurdzhieva v kontekste duhovnyh iskanij sovremennosti [The doctrine of man G.I. Gurdjieff in the context of modern spiritual quests]. Diss... Cand. Philos. sciences (PhD). Rostov-na-Donu, 141.

27. Kurakina O.D. 2014. Russkij kosmizm - mirovozzrenie russkoj civilizacii [Russian cosmism - the outlook of Russian civilization]. In: Bulgakovskie chteniya [Bulgakov readings]. 8: 6-12.

28. Lemeshev O. (deacon). 2019. Misticheskoe uchenie o «sovesti»v okkul'tnoj koncepcii «Chetvyortogo puti» [The mystical doctrine of «conscience» in the occult concept of the «Fourth Way»]. In: Voprosy bogosloviya [Questions of theology]. T. 2. 2: 70-87.

29. Lunin B.V. 1958. Iz istorii russkogo vostokovedeniya $\mathrm{i}$ arheologii $\mathrm{v}$ Turkestane. Turkestanskij kruzhok lyubitelej arheologii (1895-1917) [From the history of Russian oriental studies and archeology in Turkestan. Turkestan circle of archeology amateurs (1895-1917)]. Tashkent, AN Uzbekskoj SSR, 320.

30. Nezhinskij I.V. 2009. Ezotericheskoe hristianstvo Georgiya Gurdzhieva [Esoteric Christianity of George Gurdjieff]. In: Sajt «Chetvertyj put'. Gurdzhiev - Uspenskij - Sufizm» [Website «The Fourth Way. Gurdjieff - Uspensky - Sufism»]. Available at: http://fway.org/articles/261-2009-0313-20-35-10.html (accessed 1 February 2021) (in Russian).

31. Orlov I.O. 2006. Nauchnaya revolyuciya konca XIX - nachala XX veka [Scientific revolution of the late XX - early XX century]. In: Filosofiya nauki [Philosophy of Science]. 1 (28): 130-148. 
32. Pil'chinova E.V. 2014. Nauchno-tekhnicheskaya revolyuciya kak osnovnoj faktor razvitiya proizvoditel'nyh sil: istoricheskij obzor [Scientific and technological revolution as the main factor in the development of productive forces: a historical overview]. In: Vestnik Buryatskogo gosudarstvennogo universiteta [Bulletin of the Buryat State University]. 2: 22-25.

33. Pitanov V.Yu. 2016. Georgij Gurdzhiev - okkul'tist ili hristianin? [George Gurdjieff occultist or Christian] In: Personal'nyj sajt Pitanova Vitaliya Yur'evicha. Psihologiya, sravnitel'noe religiovedenie, apologetika [Personal site of Pitanov Vitaly Yurievich. Psychology, Comparative Religious Studies, Apologetics]. Available at: http://pitanov.info/georgiy-gurdzhiev-okkultist-ilihristianin (accessed 1 February 2021) (in Russian).

34. Polonskaya I.N. 2005. Filosofskie principy tradicionalizma [Philosophical principles of traditionalism]. In: Nauchnaya mysl' Kavkaza [Scientific thought of the Caucasus]. 4: 30-36.

35. Rovner A.I. 2002. Gurdzhiev i Uspenskij [Gurdjieff and Uspensky]. Moscow, Sofiya: Gelios, 509 (in Russian).

36. Sedzhvik M. 2014. Naperekor sovremennomu miru. Tradicionalizm i tajnaya intellektual'naya istoriya XX veka [Contrary to the modern world. Traditionalism and the secret intellectual history of the 20th century]. Moscow, Novoe literaturnoe obozrenie, 536.

37. Sviridovskaya N.D. 2014. Foma Gartman: neizvestnyj kompozitor kruga Taneeva i Rahmaninova [Thomas Hartmann: unknown composer of the circle of Taneyev and Rachmaninoff]. In: Nauchnyj vestnik Moskovskoj konservatorii [Scientific Bulletin of the Moscow Conservatory]. 1: 68-85.

38. Uelsh U.D. 2002. Vospominaniya [Memories]. In: Gurdzhiev. Esse i razmyshleniya o Cheloveke i ego Uchenii [Gurdjieff. Essays and Reflections on Man and His Teachings] (collection). Moscow, Strajklajt: 145-166.

39. Uspenskij P.D. 2014. V poiskah chudesnogo [In search of the miraculous]. Moscow, Enigma, 488.

40. Vanderhill E. 1996. Gurdzhiev [Gurdjieff]. In: Mistiki XX v. [Mystics of the 20th century]. Encyclopedia. Moscow, Mif; Lokid: 164-180.

41. Baker R. 2000. No Harem. Gurdjieff and the Women of The Rope. In: Gurdjieff International Review. Available at: https://www.gurdjieff.org/G.1-2.htm (accessed 1 February 2021) (in Russian).

42. Gurjieff G.I. 1953. Scenario of the Ballet «The Struggle of the Magicians». Capetown, South Africa, The Stourton Press, 44.

43. Taylor P.B. 1998. The Shadows of Heaven: Gurdjieff and Toomer. Newburyport, Red Wheel Weiser, 272.

\section{ИНФОРМАЦИЯ ОБ АВТОРЕ}

Мошкин Александр Николаевич, доктор исторических наук, профессор, ведущий научный сотрудник НИЛ исторической антропологии Белгородского государственного национального исследовательского университета, г. Белгород, Россия

\section{INFORMATION ABOUT THE AUTHOR}

Aleksandr N. Moshkin, Doctor of Historical Sciences, Professor, Leading Researcher of the Research Laboratory of Historical Anthropology, Belgorod National Research University, Belgorod, Russia 